\title{
Synthesis and Bioactivity of 1-((2-Carbamoylguanidino) (furan-2-ylmethyl)urea
}

\author{
Chioma Donlawson ${ }^{1 *}$, Daniel Okechukwu Nweneka ${ }^{1}$, Kingsley John Orie ${ }^{2}$, Reminus Okah ${ }^{1}$ \\ ${ }^{1}$ Department of Science Laboratory Technology, Captain Elechi Amadi Polytechnic, Rumuola, Nigeria \\ ${ }^{2}$ Department of Pure and Industrial Chemistry, University of Port Harcourt, Port Harcourt, Nigeria \\ Email: ${ }^{\star}$ ogweru12345@gmail.com
}

How to cite this paper: Donlawson, C., Nweneka, D.O., Orie, K.J. and Okah, R. (2020) Synthesis and Bioactivity of 1-((2Carbamoylguanidino)(furan-2-ylmeth-yl)urea. American Journal of Analytical Chemistry, 11, 280-288.

https://doi.org/10.4236/ajac.2020.117022

Received: February 23, 2020

Accepted: July 19, 2020

Published: July 22, 2020

Copyright $\odot 2020$ by author(s) and Scientific Research Publishing Inc. This work is licensed under the Creative Commons Attribution International License (CC BY 4.0).

http://creativecommons.org/licenses/by/4.0/

\begin{abstract}
1-((2-Carbamoylguanidino)(furan-2-ylmethyl)urea was synthesised by coupling purified furfural with urea. The compound was characterized by GC-MS, FTIR, and ${ }^{1} \mathrm{H}-\mathrm{NMR}$. The pathogens, Escherichia coli, Salmonella typhi, Staphylococcus aureus and Bacillus subtilis were isolated and screened with different concentrations of 1-((2-carbamoylguanidino)(furan-2-ylmethyl)urea. All the pathogens were susceptible to the synthesized compound except Bacillus subtilis. Due to this broad spectrum of activity, 1-((2-Carbamoylguanidino)(furan-2-ylmethyl))urea) can be use for various medicinal purposes and is therefore encouraged for the development of a novel drug in future.
\end{abstract}

\section{Keywords}

Furfural, 1-((2-Carbamoylguanidino)(furan-2-ylmethyl)urea, Bioactivity

\section{Introduction}

In the last decades, there has been a growing interest in synthesis, researching and developing new antimicrobial agents from various sources to combat microbial resistance [1]. Currently, microbial infections have become an important clinical threat, with significant associated morbidity and mortality which is mainly due to the development of microbial resistance to the existing antimicrobial agents [2]. Microbial resistance to antibiotics is one of the most important global health problems, justifying the necessity of innovation; most synergic radical antimicrobial agents have emerged [1] [3]. The antibiotic resistance problem is amplified by the ability of bacteria to grow in an adherent state, developing microbial communities called biofilms, which exhibit a phenotypic resistance, 
i.e. tolerance, rendering them to1000-fold more resistant to antibiotic treatments when compared to their planktonic counterparts [4]. The important hallmarks of chronic biofilm-based infections are extreme resistance to antibiotics and many other conventional antimicrobial agents, and an extreme capacity for invading the host defences [5].

Furfural is a heteroaromatic aldehyde (furan-2-carbaldehyde) produced from a variety of agricultural by-products [6] and is obtained by hydrolysis and dehydration of pentose carbohydrates contained in lignocellulose [7]. It is a chemical that is potentially relevant in organic synthesis due to its cheapness and bio-availability [7] [8]. It is an essential chemical in the synthesis of furan; an intermediate for the production of pharmaceutical drugs and fine chemicals in the industries (Eseyin \& Steele, 2015). It serves as an agricultural nematocide: it is used to control plant-parasitic nematodes without adversely affecting the growth and yield of the plant (Rodriguez-Kabana, Kloepper, Weaver, \& Robertson, 1993). Furfural does not kill the nematodes directly but promotes a bacterial activity that acts as an antagonist, thus influencing the biological activity of the nematodes (Zeitsch, 2000). Due to low acute and ecological, non-systematic (not absorbed by the plant) and safe applicability to the soil through water solution, furfural is seen as a biomass-derived active ingredient in nematocide formulation for agriculture products (Rodriguez-Kabana et al., 1993).

Furfural has gained attention as a potential chemical for organic synthesis since its derivatives have outlets in the chemical and pharmaceutical industries [9]. It has also served as a precursor in the synthesis of the following [10], furfurymaleic acid [11], 5-(3-nitrophenyl)-4-(2-furyl)-3-buten-2-one [12], nitrofurazone [13], etc.

Heterocyclic compounds are important to human life because their structural subunits exist in many natural products such as vitamins, hormones, antibiotics and pigments. Furfural derivatives are the subject of many research studies due to their widespread potential biological activities such as antimicrobial [13], antiviral [14], antioxidant [15], antitumor, antihistaminic and fungicides [16]. These have rendered furfural derivatives valuable active ingredients of medicine and plant protecting agents. These compounds are useful in the field of medicine and are used as a starting material for the synthesis of a new drug [16].

Urea is an important nitrogen-containing compound that has proved to be useful substances in drug research in recent years [13] [17]. Some urea derivatives possess valuable antituberculosis, antibacterial and anticonvulsant properties [18]. Thioureas can be used in the control of plant pathogens like Penicillum expansum and Fusarium oxysporum [19]. Urea is a raw material for the production of two main classes of chemical substances; urea-formaldehyde resins and urea melamine-formaldehyde which are used in marine plywood. It has the highest nitrogen content of all the nitrogenous fertilizer commonly used in agriculture [20]. Emmanuel et al. [21] reported for the first time the antifungal 
activity of 2-aminooxazole thiourea derivatives against Botrytis cinerea.

Synthetic medicinal chemistry, with the skill, wisdom and effort has proven to be a major endeavour not only confined to the laboratories of universities in general, but also to the bulkdrug industry in particular [22]. Biological activity of a compound is a function of the structure [23]. Minor changes may cause prominent implication overactivity. Replacement of one group by the other in a specific location in the molecule may sometimes completely reverse the action of the compound [24]. The probable points of differences amongst the antibiotics may be physical, chemical, pharmacological properties, antibacterial spectra and mechanism of action [25]. In view of these data, we have undertaken the synthesis, characterization and antimicrobial evaluation of 1-((2-Carbamoylguanidino)(furan-2-ylmethyl)urea. The unique fact about this paper is that the bioactivity of this furfural derivative, 1-((2-Carbamoylguanidino)(furan-2-ylmethyl)urea has not been reported in the literature.

\section{Materials and Methods}

FTIR 8400S Fourier Transform Infrared spectrophotometer was used to identify the functional groups, Gas Chromatography/Mass Spectrometer-QP2010 PLUS SHIMADZU was used for molecular formula/mass identification, Nuclear Magnetic Resonance(Agilent-NMR-VNMRS400) was used for structural elucidation, Vacuum Pump (TKS-70), for vacuum distillation of furfural and Digital Melting Point Electrothermal IA9300X1, for melting point determination. Furfural was bought from a chemical store and purified by vacuum distillation. Other chemicals such as urea, ethanol, and sodium hydroxide were of Analar grade and used without further purification. Thin-layer chromatography (TLC) was carried out using a Merck pre-coated silica gel plate $(10 \times 10 \mathrm{~cm})$; the $\mathrm{Rf}$ value was obtained using a solvent mixture of $n$-hexane and ethyl acetate in a ratio of 2:3. The chromatogram was visualized using an ultraviolet lamp at 256 $\mathrm{nm}$.

\subsection{Synthesis of \\ 1-((2-Carbamoylguanidino)(furan-2-ylmethyl))urea}

The furfural used in this study was bought from a chemical store. The deteriorated furfural was purified by vacuum distillation at the temperature of $65^{\circ} \mathrm{C}$ to $80^{\circ} \mathrm{C}$. The procedure adopted in the synthesis of 1-((2-Carbamoylguanidino)(furan-2-ylmethyl)urea was earlier reported by Orie et al. [26]. The purified furfural $(40 \mathrm{~mL}, 0.48 \mathrm{~mol})$, urea $(40 \mathrm{~g}, 0.63 \mathrm{~mol})$ and distilled water $(9 \mathrm{~mL})$ were placed in a flat-bottomed flask $(250 \mathrm{~mL})$ and the mixture heated in a water bath a temperature of $60^{\circ} \mathrm{C}$ for 1 hour, 40 minutes with vigorous stirring. Thereafter, $\mathrm{NaOH}$ ( $2 \mathrm{~mL}$ of $20 \%$ of solution) was added and the heating continued for 20 minutes. The mixture was cooled in an ice bath and the resulting brown precipitate filtered, washed with n-hexane, recrystallized from methanol and the crystal dried in an oven at $50^{\circ} \mathrm{C}$. 


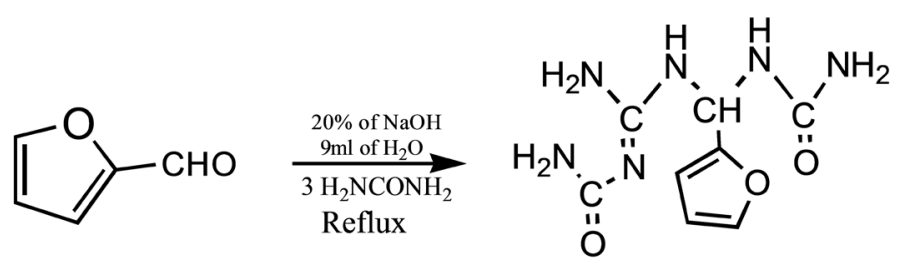

Synthesis of 1-((2-Carbamoylguanidino)(furan-2-ylmethyl))urea.

\subsection{Pathogen Isolation}

The test pathogens (Escherichia coli, Salmonella typhi, Staphylococcus aureus and Bacillus subtilis) that were used for the antimicrobial screen were isolated from clinical samples obtained from Beracah Hospitals, Rukpokwu, Port Harcourt, Rivers State.

\subsection{DMSO Solubility Screen}

This was done to determine the concentrations of DMSO (ranging from $10 \% \mathrm{v} / \mathrm{v}$ to $100 \% \mathrm{v} / \mathrm{v}$ ) that best dissolves test compounds/agents to be used for the screen. To carry out this screen, $0.1 \mathrm{~g}$ of each synthesized agent was suspended in 100 $\mathrm{mL}$ of the different concentrations of DMSO at room temperature with continuous agitation for 12 hours. After the incubation period, the observed solubility patterns were recorded.

\subsection{Toxicity Screen}

This screen was carried out to determine the concentrations of DMSO (amongst those that achieved the best agent solubility) that did not show any inhibition pattern on the test microbial pathogens. The well-in-agar diffusion method was used to carry out this screen, where $10 \mu \mathrm{L}$ of these different DMSO concentrations were introduced into wells ( $5 \mathrm{~mm}$ diameter) dug into Mueller Hinton agar plates inoculated with the different test pathogens $\left(10^{8}\right.$ cells). After the introduction, the plates were incubated at $37^{\circ} \mathrm{C}$ for 24 hours. After incubation, observed zones of inhibition for the different DMSO concentrations screened, for the different test pathogens were recorded, with their average inhibition being determined. The DMSO concentration with the best solubility pattern on the antimicrobial test agents and also non-toxic to the test pathogens was used as the solvent for preparing the different concentrations of the antimicrobial test agents in order to determine their Minimum Inhibition Concentration (MIC) and Minimum Bactericidal Concentration (MBC)

\subsection{Antimicrobial Test Agent Preparation}

Different concentrations $\left(100 \mathrm{mg} \cdot \mathrm{L}^{-1}, 10 \mathrm{mg} \cdot \mathrm{L}^{-1}, 1 \mathrm{mg} \cdot \mathrm{L}^{-1}, 0.1 \mathrm{mg} \cdot \mathrm{L}^{-1}, 0.01 \mathrm{mg} \cdot \mathrm{L}^{-1}\right.$, and $0.001 \mathrm{mg} \cdot \mathrm{L}^{-1}$ ) of the antimicrobial test agents (Sample A) were prepared using serial dilution method with $50 \% \mathrm{v} / \mathrm{v}$ DMSO contained in different sterile test tubes and labeled appropriately. 


\subsection{Minimum Inhibitory Concentration (MIC) Screen}

This screen was done to determine the least concentration of the test agents that is capable of inhibiting the growth of each microbial test pathogens. The screen was also carried out using the well-in-agar diffusion method. For each test pathogen that was screened, a cell concentration of $10^{8}$ cells was first inoculated into Mueller Hinton agar plates, after which wells $(5 \mathrm{~mm}$ diameter) were dug and filled $(10 \mu \mathrm{L})$ with the different concentrations of each of the test agent. The plates were then incubated for $12-24$ hours at $37^{\circ} \mathrm{C}$. After incubation, the observed zones of inhibition for each concentration of each test agent on each test pathogen were recorded. MIC concentration was then determined by looking out for that particular minimum concentration of the test agent that was capable of inhibiting the growth of a given test pathogen.

\subsection{Minimum Bactericidal Concentration (MBC) Screen}

This screen was carried out to determine the least concentration of the test agents that is capable of inhibiting the growth of each microbial test pathogen by killing their cells. For each microbial pathogen, $0.1 \mathrm{~mL}$ of the cells $\left(10^{8}\right)$ was introduced into test tubes containing $5 \mathrm{~mL}$ of the different concentrations of the different samples and incubated for 24 hours at $37^{\circ} \mathrm{C}$. After incubation, a loopful of the incubated concentrations was spread onto the surface of freshly prepared Mueller Hinton agar plates and further incubated $37^{\circ} \mathrm{C}$ for 24 hours. After incubation, the minimum concentration of each sample that showed cell death (determined by the absence of visible colonies on Mueller Hinton agar plates after incubation) for a given pathogen, was considered the MBC.

\section{Results and Discussion}

Table 1 shows the physio-chemical properties, FTIR and NMR results of 1-((2Carbamoylguanidino)(furan-2-ylmethyl))urea), these results are in line with Emmanuel et al. and Orie et al.

From the results presented in Table 2, it was extrapolated that 1-((2-Carbamoylguanidino)(furan-2-ylmethyl))urea) has an antibacterial activity on all the test pathogens with the exception of Bacillus subtilis, given that all concentrations showed no inhibition zones on the pathogen (Table 2).

The efficacy of this activity on the different test pathogens varied as indicated by their MIC readings (Table 2). The sample showed the most activity on Salmomellatyphi because it is the organism with the least concentration of the sample $\left(0.001 \mathrm{mg} \cdot \mathrm{L}^{-1}\right)$ as its MIC. The second most susceptible pathogen to the sample was Escherichia coli $\left(0.01 \mathrm{mg} \cdot \mathrm{L}^{-1}\right)$, while the least susceptible pathogen was Staphylococcus aureus $\left(1.0 \mathrm{mg} \cdot \mathrm{L}^{-1}\right)$. Bacillus subtilis was not inhibited by the agent.

With the exception of Bacillus subtilis, the sample has a bactericidal action on the test pathogens, but also at varied concentrations. For Escherichia coli, concentrations that are above $0.1 \mathrm{mg} \cdot \mathrm{L}^{-1}$ will bring about the death of cells. For Sta- 
phylococcus aureus, concentrations below $1.0 \mathrm{mg} \cdot \mathrm{L}^{-1}$ will bring about the death of cells, while for Salmonella typhi, concentrations that are below $0.1 \mathrm{mg} \cdot \mathrm{L}^{-1}$ will bring about the death of cells. Table 3 shows Minimum Bactericidal Concentration (MBC) of CFM on Test Pathogens. The compound CFM exhibited both bactericidal and bacteriostatic properties when screened on the pathogens. Bactericidal mode of inhibition was observed with Escherichia coli and Salmonella typhi, while bacteriostatic mode of inhibition was observed with Bacillus subtilis.

Table 1. Structural elucidation of the 1-((2-Carbamoylguanidino)(furan-2-ylmethyl))urea).

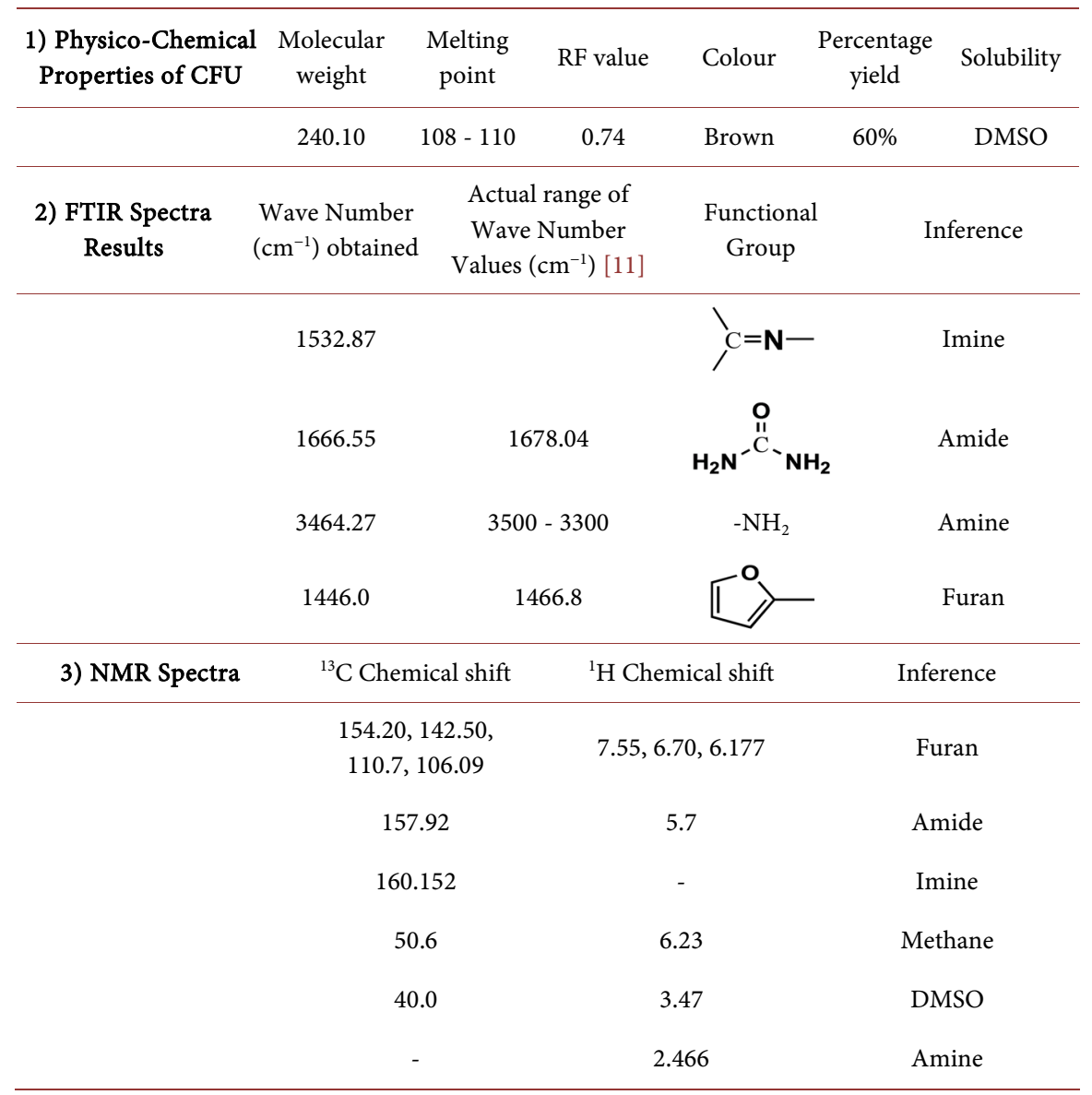

Table 2. Activity of 1-((2-Carbamoylguanidino)(furan-2-ylmethyl))urea) on test pathogens.

\begin{tabular}{|c|c|c|c|c|c|c|c|}
\hline \multirow{2}{*}{ S/No. } & \multirow{2}{*}{ Pathogens } & \multicolumn{6}{|c|}{ Concentrations $\left(\mathrm{g} \cdot \mathrm{L}^{-1}\right) /$ Inhibition diameter $(\mathrm{mm})$} \\
\hline & & $100 \mathrm{mg} \cdot \mathrm{L}^{-1}$ & $10 \mathrm{mg} \cdot \mathrm{L}^{-1}$ & $1 \mathrm{mg} \cdot \mathrm{L}^{-1}$ & $0.1 \mathrm{mg} \cdot \mathrm{L}^{-1}$ & $0.01 \mathrm{mg} \cdot \mathrm{L}^{-1}$ & $0.001 \mathrm{mg} \cdot \mathrm{L}^{-1}$ \\
\hline 1 & E. coli & 14.6 & 12.1 & 11.4 & 9.0 & $* 8.5$ & 0 \\
\hline 2 & $S$. aureus & 8.7 & 8.0 & *7.5 & 0 & 0 & 0 \\
\hline 3 & S. typhi & 11.9 & 10.8 & 10.1 & 8.0 & 6.0 & *5.5 \\
\hline 4 & B. subtilis & 0 & 0 & 0 & 0 & 0 & 0 \\
\hline
\end{tabular}

Well diameter: $5 \mathrm{~mm}$; ${ }^{\star}=$ Minimum Inhibitory Concentration (MIC). 
Table 3. Minimum Bactericidal Concentration (MBC) of 1-((2-Carbamoylguanidino)(furan-2-ylmethyl))urea) on test pathogens.

\begin{tabular}{cccccccc}
\hline & & \multicolumn{5}{c}{ Concentrations $\left(\mathrm{g} \cdot \mathrm{L}^{-1}\right) /$ Inhibition diameter $(\mathrm{mm})$} \\
\cline { 3 - 7 } S/No & Pathogens & & \multicolumn{5}{c}{} \\
\cline { 3 - 7 } & & $100 \mathrm{mg} \cdot \mathrm{L}^{-1}$ & $10 \mathrm{mg} \cdot \mathrm{L}^{-1}$ & $1 \mathrm{mg} \cdot \mathrm{L}^{-1}$ & $0.1 \mathrm{mg} \cdot \mathrm{L}^{-1}$ & $0.01 \mathrm{mg} \cdot \mathrm{L}^{-1}$ & $0.001 \mathrm{mg} \cdot \mathrm{L}^{-1}$ \\
\hline 1 & E. coli & - & - & - & $*$ & + & + \\
2 & S. aureus & - & - & $*$ & + & + & + \\
3 & S. typhi & - & - & - & $*$ & + & + \\
4 & B. subtilis & + & + & + & + & + & + \\
\hline
\end{tabular}

${ }^{*}$ Minimum Bactericidal Concentration (MBC).

\section{Conclusion}

1-((2-Carbamoylguanidino)(furan-2-ylmethyl))urea) possesses a broad spectrum of antimicrobial activities and thus, a potential candidate for a prospective antimicrobial treatment. Due to this broad spectrum of activity, 1-((2-Carbamoylguanidino)(furan-2-ylmethyl))urea) can be used for various medicinal purposes and is therefore encouraged. The presence of bioactive moieties and pharmacological activities proved the potency of furfural derivatives in the development of novel drug in the future.

\section{Conflicts of Interest}

The authors declare no conflicts of interest regarding the publication of this paper.

\section{References}

[1] Maria, M. (2017) 2-Aminopyridine-A Classic and Trendy Pharmacophore. International Journal of Pharma and Bioscience, 8, 338-355.

https://doi.org/10.22376/ijpbs.2017.8.2.p338-355

[2] Dueke-Eze, C.U., Fasina, T.M. and Mphahlele, M. (2013) Synthesis, Characterization and Solvent Effects on the Electronic Absorption Spectra of Aminopyridine Schiff Bases. Asian Journal of Chemistry, 25, 8505-8508.

https://doi.org/10.14233/ajchem.2013.14805

[3] Ananthalakshmi, S.K., Kiriethika, R.A. and Kalavani, A. (2014) Synthesis, Characterization and Antimicrobial Studies of Tosyl Ester of Carboxylic Acid. International Journal of Scientific and Research Publication, 4, 1-14.

[4] Nagashree, M.P., Mallesha, L. and Bindya, R. (2015) Antimicrobial Activity of Methyl-3-aminopyridine-4-carboxylate Derivatives. Hindawi Journal of Chemistry, $\mathbf{5}$, 700-705.

[5] Tayebee, R. and Nehzat, F. (2012) A Simple and Effective Methodology for Sulfonylation of Alcohol and Aniline under Solvent-Free Condition at Room Temperature. American Journal of Medicine and Medical Sciences, 2, 36-39. https://doi.org/10.5923/j.ajmms.20120201.08

[6] Döbereine, J.W. (1832) Ueber die medicinische und Chemische Anwendung und die vortheilhafte darstellung der Ameisensäure. Berichte der deutschen chemischen Gesellschaft, 3, 141-146. https://doi.org/10.1002/jlac.18320030206 
[7] Ngochindo, R.I. (1995) Furfural in a Developing Economy. Rhomers System, Eleme, Rivers State, Nigeria.

[8] Machado, G., Leon, S., Santos, F., Lourega, R., Dullius, J., Mollmann, M.F. and Eichler, P. (2016) Literature Review on Furfural Production from Lignocellulosic Biomass. Natural Resources, 7, 115-129. https://doi.org/10.4236/nr.2016.73012

[9] Eseyin, E.A. and Steele, P.S. (2015) An Overview of the Application of Furfural and Its Derivatives. International Journal of Advanced Chemistry, 3, 42-47. https://doi.org/10.14419/ijac.v3i2.5048

[10] Rodriguez-Kabana, R., Kloepper, J.W., Weaver, C.F. and Robertson, D.G. (1993) Control of Plant-Parasitic Nematodes with Furfural-A Naturally Occurring Fumigant. Nematropica, 23, 63-73.

[11] Zeitsch, K.J. (2000) The Chemistry and Technology of Furfural and Its Many By-Product. Sugar Series, 13, 12-23.

[12] Yen, K., Iva, G., Lafleur, T. and Jarvis, C. (2014) Production, Properties and Catalytic Hydrogenation of Furfural to Fuel Additive and Value Added Chemicals. Renewable and Sustainable Energy Reviews, 38, 663-676.

https://doi.org/10.1016/j.rser.2014.07.003

[13] Raman, J.K. and Gnansounou, E. (2015) Furfural Production from Empty Fruit Bunch-A Biorefinery Approach. Industrial Crops and Products, 69, 137-377. https://doi.org/10.1016/j.indcrop.2015.02.063

[14] Yedi, M.A., Lebigot, Y., Ammar, H., Abid, S., Elgharbi, R. and Delmas, M. (2012) Simple Novel Synthesis of Furfurylamine from Furfural, by One-Pot Reductive Amination in Water Using Zinc Metal. Journal Dela Societe De Tunisie, 14, 109-116.

[15] Jumina, I., et al. (2002) Synthesis and Antimicrobial Activity Evaluation of Ethyl Salicyl Fumarate and Ethyl Furfuryl Fumarate. Majalah Farmasi Indonesia, 10, 207-214.

[16] Mukhtar, A., Wani, L., Javeed, A., Farooqi, I. and Wajahat, A.S. (2016) Synthesis and Antimicrobial Activity of Some Furfural Substituted Bisdimedone Derivatives. Journal of Pharmaceutical and Applied Chemistry. An International Journal, 2, 53-57. https://doi.org/10.18576/jpac/020204

[17] Wilson, E. and Gisvold, A. (1991) Text Book of Organic Medicinal and Pharmaceutical Chemistry. 9th Edition, J. B. Lippin Colt Company, Philadelphia.

[18] Abeeral, S., Khalil, W. and Merza, J. (2018) Preparation and Spectroscopic Study of the Reaction of 4-Nitroacetophenone, Furfural and Thiourea. Chemistry and Materials Research, 10, 41-46.

[19] Giovanoni, R. and Warren, R.G. (1983) Principles of Pharmacology. C.V. Mostry, London.

[20] Shargel, L. (1992) Comprehensive Pharmacy Review. 2nd Edition, 183.

[21] Marsh, K.L., Sim, G.K. and Mulvaney, R.L. (2005) Availability of Urea to Autotrophs, Ammonia-Oxidizing Bacteria as Related to Fate of ${ }^{14} \mathrm{C}$ and ${ }^{15} \mathrm{~N}$-Labelled Urea Added to Soil. Biology and Fertility of Soil, 42, 137. https://doi.org/10.1007/s00374-005-0004-2

[22] Emmanuel, A., Thomas, S.A., Idris, S.O. and Iyun, J.F. (2013) Complex of $\mathrm{Zn}(11)$ and $\mathrm{Cd}(11)$ with 1-(Furan-2-ylmethylene)urea and N-(Propan-2-ylidene)benzohydrazide. International Journal of Chemical Research, 5, 140-143. https://doi.org/10.9735/0975-3699.5.1.140-143

[23] Krasnoff, S.B., Faloon, D., Williams, E. and Gibson, D.M. (1999) Toxicity of Xanthene Dyes to Entomopathogenic Fungi. Biocontrol Science and Technology, 9, 215. 
https://doi.org/10.1080/09583159929794

[24] Martin, P.A.W., Mischke, S. and Schroder, R.F.W. (1998) Compatibility of Photoactive Dyes with Insect Biocontrol Agents. Biocontrol Science and Technology, 8, 501. https://doi.org/10.1080/09583159830018

[25] McQuate, G.T., Cunningham, R.T., Peck, S.L. and Moore, P.H. (1999) Suppressing Oriental Fruit Fly Populations with Phloxine B Protein Bait Sprays. Pesticide Science, 55, 574.

https://doi.org/10.1002/(SICI)1096-9063(199905)55:5<574::AID-PS952>3.0.CO;2-Y

[26] Jeyakanthan, J. and Velmurugan, D. (1999) The Crystal and Molecular Structure of 1,8-Dioxo-9-(o-nitrophenyl)1,2,3,4,5,6,7,8-octahydro-xanthene. Crystal Research and Technology, 34, 1339-1344.

https://doi.org/10.1002/(SICI)1521-4079(199912)34:10<1339::AID-CRAT1339>3.0. CO;2-3 